\title{
Groundwater nitrate pollution in the recharge zone of a regional Quaternary flow system (Wielkopolska region, Poland)
}

\author{
Krzysztof Dragon
}

Received: 26 January 2012/ Accepted: 1 August 2012/Published online: 19 August 2012

(C) The Author(s) 2012. This article is published with open access at Springerlink.com

\begin{abstract}
The present study examines the behaviour of nitrate in the recharge zone of a regional Quaternary flow system. The presence of contaminated groundwater with high nitrate content in the shallow part of the flow system was documented. Tritium analyses confirmed that these contaminants can migrate downward. A high downward gradient exists in the study area, extending into the regions of groundwater extraction. In the unconfined part of the flow system, which is the most vulnerable to pollution, a high concentration of nitrate was found to occur at great depth. However, denitrification processes limit nitrate migration. As a result, in the deeper parts of the flow system in regions under confined conditions, an absence of nitrate was observed, and a higher sulphate concentration and total hardness were evident. The denitrification was also confirmed by the existence of a high gaseous $\mathrm{N}_{2}$ concentration. It was documented that denitrification occurs in both the confined and unconfined parts of the flow system, but the potential for denitrification is higher in the confined parts (leading to the disappearance of nitrate in deep aquifers). Autotrophic denitrification supported by sulphide compounds was indicated as the dominant denitrification process.
\end{abstract}

Keywords Groundwater contamination - Nitrate . Denitrification - Gaseous $\mathrm{N}_{2}$. Buried valley aquifer . Poland

\section{K. Dragon $(\bowtie)$}

Department of Hydrogeology and Water Protection, Institute of Geology, Adam Mickiewicz University Poznan, Makow Polnych Street 16, 61-606 Poznan, Poland

e-mail: smok@amu.edu.pl

\section{Introduction}

Nitrate contamination of groundwater is a common phenomenon that is observed in many parts of the world (e.g., Hudak 2000; Rodvang and Simpkins 2001; Chen et al. 2005). High nitrate concentrations in drinking water are linked to health problems because these cause methemoglobinemia in infants and stomach cancer in adults. Because nitrate can cause significant health problems in humans, the European Union, the World Health Organization and the Polish legal system have determined the maximum allowable concentration of nitrate in potable water to be $50 \mathrm{mg} \mathrm{NO}_{3} / 1\left(11.3 \mathrm{mg} \mathrm{N}-\mathrm{NO}_{3} / \mathrm{l}\right)$ (Drinking Water Directive 98/83/EC 1998; WHO 2004; Rozporzadzenie MZ 2007). To protect groundwater from nitrate pollution, restrictions have been implemented on the application of nitrogen to land, especially in designated zones containing vulnerable aquifers (Nitrates Directive 91/676/EEC 1991). These conditions have environmental, social and economic consequences.

The problem of nitrate groundwater contamination mainly occurs in shallow groundwater systems. However, in some cases, contamination can also occur in deeper parts of the flow system. The recharge zones of regional extended aquifers, in which a distinct downward gradient causes a descending flow, are predictable areas of groundwater pollution (Chen et al. 2005). This factor is significant, especially in unconfined areas of the regional aquifers (which are the most vulnerable to pollution from the surface). Water extraction is one factor that can noticeably activate or accelerate contaminant migration. This factor can create a downward gradient, even in areas where such a gradient does not occur under natural conditions (e.g., regional discharge zones and through-flow areas). 
Fig. 1 The location of the study area on a background of the land relief. 1 The boundaries of the major groundwater basins, 2 surface water (lakes and rivers), 3 general groundwater flow directions, 4 the study area, 5 the lines of cross sections: $A$ I-I', B II-II' (Fig. 2)

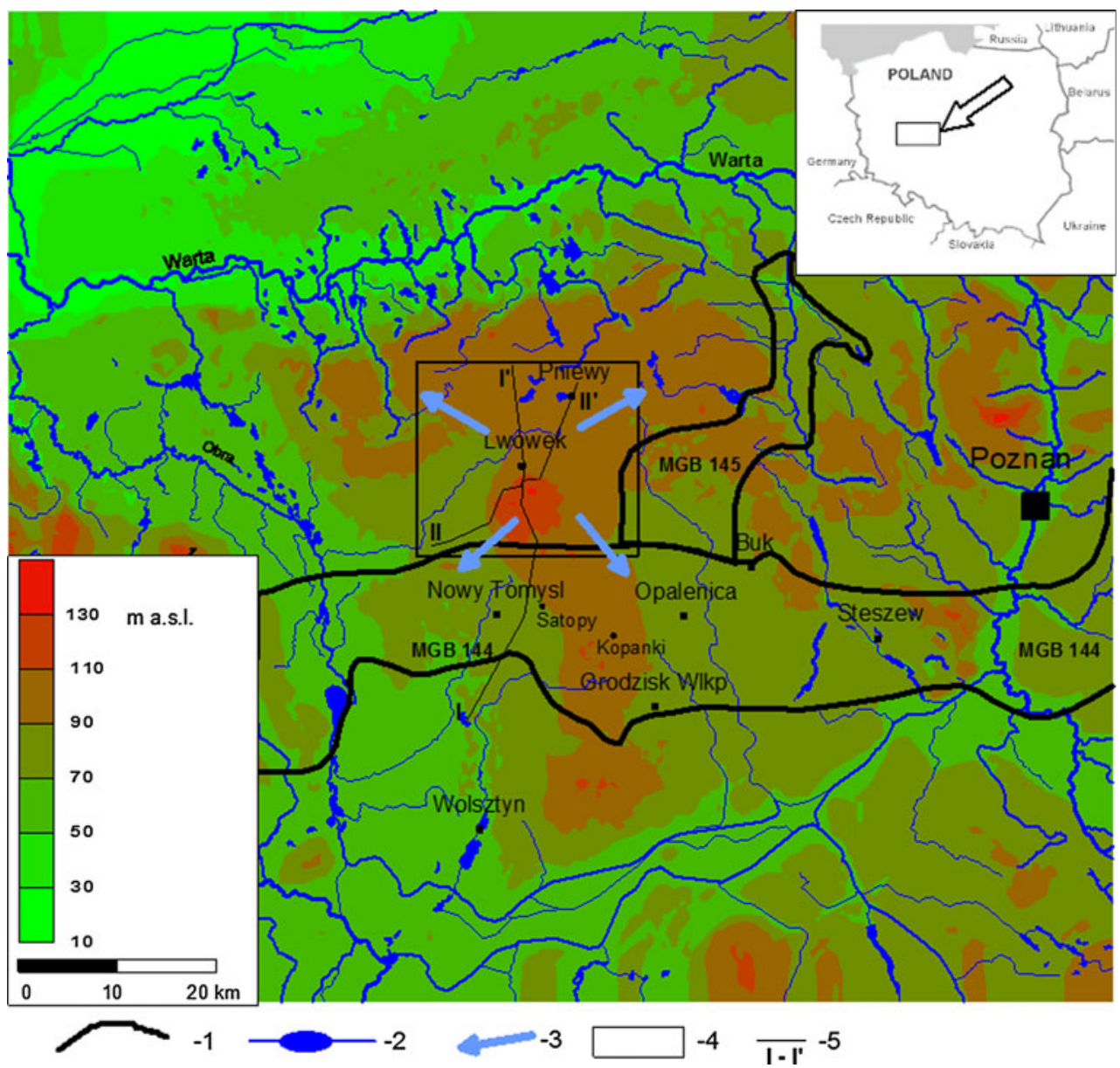

One natural mechanism for removing nitrate from a system is bacterial denitrification. This process has been documented in a number of groundwater systems (Bennekom et al. 1993; Rivers et al. 1996; Aravena and Robertson 1998; Einsield et al. 2005; Craig et al. 2010; Zurek et al. 2010). In general, this process is effective under anaerobic conditions, in which electron donors, such as dissolved organic carbon, sedimentary organic matter or the reduced form of sulphur, are available. In some aquifer systems, denitrification within the aquitard has been documented (Robertson et al. 1995; Feast et al. 1998; Rodvang and Simpkins 2001). This denitrification is manifested by the absence of nitrate, even in regions that are strongly influenced by agricultural activities, where a high content of nitrate occurs in shallow flow systems.

The research presented in this article was conducted in the regional recharge zone of a Quaternary groundwater flow system (the Wielkopolska region of Poland). The main objectives of this study were the investigation of the behaviour of nitrate in relation to the flow system and the documentation of the denitrification processes present in the aquifer/aquitard system.

\section{Study area}

\section{Hydrogeological setting}

The study area is located in the highest elevation area of the Lwowek-Rakoniewice Rampart. For a detailed analysis of the water chemistry, the central part of the recharge area was selected, where there are locally unconfined conditions that cause intensive aquifer recharge. This part of the aquifer system is the most vulnerable to groundwater contamination.

The elevation in the central part of the region is $138 \mathrm{~m}$ a.s.l. From this peak, the elevation decreases in all directions to $100 \mathrm{~m}$ a.s.l. in the northeastern part of the region and approximately $80 \mathrm{~m}$ a.s.l. in the southeastern part (Fig. 1).

The thickness of the Quaternary sediments is more than $130 \mathrm{~m}$ in the central part of the region, decreasing to approximately $70 \mathrm{~m}$ in the southern and northern directions (Fig. 2). The lithology of these sediments is dominated by glacial and fluvioglacial deposits. The fluvioglacial sands and gravels form the aquifers, which create a multilayer aquifer system. The deepest aquifers have a thickness of 

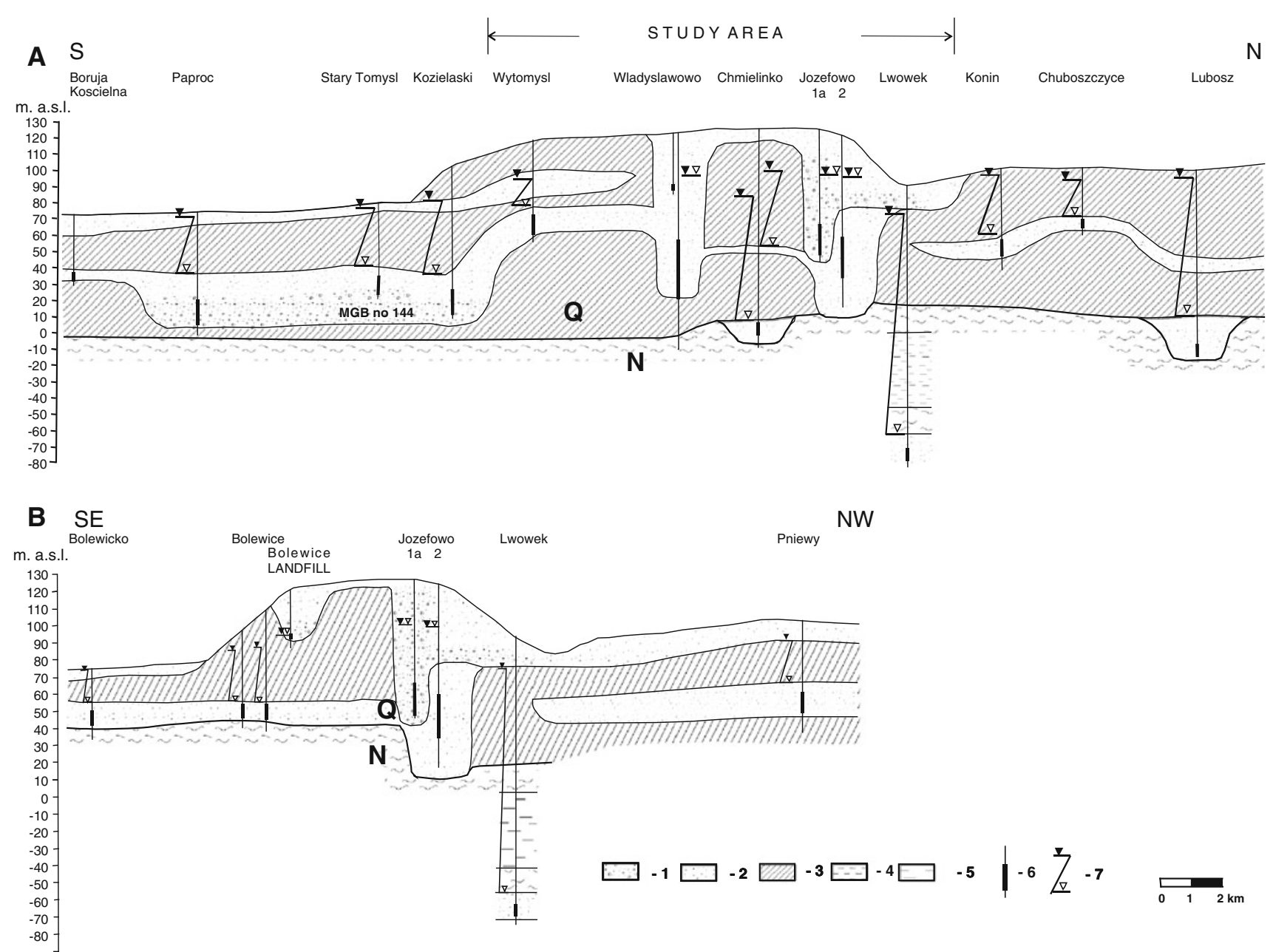

Fig. 2 The hydrogeological cross sections. 1 Coarse sand and gravel, 2 medium and fine sand, 3 till, 4 clay, 5 brown coal, 6 silt, 7 the location of the well screen, 8 ground water level, $Q$ Quaternary, $N$ neogene

approximately $20 \mathrm{~m}$ and are composed of fine sands. The shallower aquifer system has a variable thickness (between 5 and $20 \mathrm{~m}$ ) and is composed primarily of fine and medium sands. The confining layers of these aquifers are composed of glacial tills of variable thickness (Fig. 2). In some regions (Jozefowo and Wladyslawowo), the aquifer is characterised by unconfined conditions (Fig. 2a), in which sands and gravels occur from the surface to a depth of more than $100 \mathrm{~m}$. It is characteristic of these regions that the lithology is highly variable, even in wells located very close to each other. For example, in the profile of well no. 2 in Jozefowo, grey, fine and medium sands prevail, whereas in well no. 1a, coarse yellow sands and gravels occur. The unconfined parts of the aquifer system remain in hydraulic connection with the shallower confined aquifer system, whereas glacial tills cause the deepest aquifers to be isolated (Fig. 2).

The principal sources of the recharge are the direct infiltration of water into the unconfined parts of the aquifer system and the percolation of water through the glacial tills from the shallower to the deepest parts of the flow system. The infiltration occurs mainly during the winter half-year, when evapo-transpiration is declined. The amount of rainfall recharge estimated with use of numerical modelling for unconfined aquifers is 16,4 and $8,0 \mathrm{~m}^{3} / \mathrm{h} / \mathrm{km}^{2}$ for intertill aquifers. (Dabrowski 1999).

The highest downward gradient occurs in the central part of the study area. The difference in the piezometric water level between the deepest and shallowest aquifers is more than 14,0 m locally (the well in Chmielinko-Fig. 2). The general flow lines follow the main morphologic features (Fig. 1), and water flows from the central part of the Lwowek-Rakoniewice Rampart in all directions (Fig. 3).

Major Groundwater Basin no. 144 is located to the south of the study area (Wielkopolska Buried Valley) and Major Groundwater Basin no. 145 is situated to the east (Figs. 1, 2) (Kleczkowski 1990). The groundwater chemistry of these aquifers is highly influenced by the inflow of groundwater from the study area (Dragon and Górski 2009). 


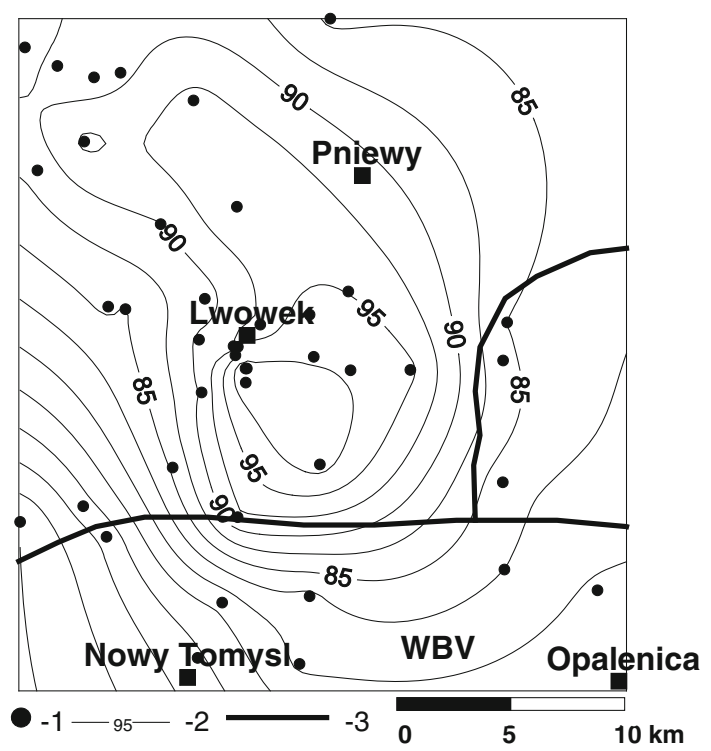

Fig. 3 A contour map of the groundwater piezometric level (constructed using the kriging method based on archival data collected during the wells' construction). 1 Wells, 2 the groundwater piezometric level [m a.s.1.] estimated based on archival data collected during the wells' construction, 3 the boundaries of the major groundwater basins

\section{Land use pattern and urbanisation}

There are two towns in the study area. The town of Lwowek is located in the central part of the study area and has 3,000 inhabitants. The town of Pniewy (7,700 inhabitants) is located in the northwestern corner of the study area. There are sewerage systems in these towns, each connected with a central sewage treatment station. A similar system is located in the village of Bolewice (1,600 inhabitants), but it does not serve the entire village. It should be emphasised that these systems are relatively new: both were constructed during the last decade. The remaining villages in the area do not have central sewerage systems. Domestic sewage is stored in individual septic tanks, which are often imperfectly constructed and poorly maintained or used. This situation causes the leakage of untreated liquid waste into the ground and into the groundwater. The land use outside the rural and urban developed areas is dominated by agricultural activity. Both the use of chemical fertilisers and manure spreading on the land are potential sources of groundwater contamination. Manure is often stored in large piles before being spread on the fields. Several gravel pits located in the study area create another danger to the groundwater, because most of these pits are located in unconfined parts of the aquifer, where sands and gravels occur just below the surface. The extraction of gravel causes a reduction of the thickness of the vadose zone. When gravel extraction takes place below the water level, the vadose zone is depleted completely. Furthermore, the borrow pits create local depressions, which form local drainage basins. Another hazard is connected with the use of the borrow pits for illegal waste disposal after the gravel exploitation is completed.

\section{Materials and methods}

The examination of groundwater chemistry was performed using data from groundwater sampling collected in the summer of 2009. The results of the ten analyses conducted on productive, continuously pumped wells located in the central part of the recharge area were used. During sampling, water was poured into 100-ml HDPE polyethylene bottles. Separate samples were taken for nutrient analyses (treated with chloroform) and for iron and manganese testing (treated with $\mathrm{HNO}_{3}$ ). All bottles were rinsed three times and filled completely to prevent degassing. After sampling, water was stored in a transportable refrigerator and all the bottles were immediately transported to the laboratory on the same day. Water colour, alkalinity, electrical conductivity, $\mathrm{pH}$ and temperature were measured directly in the field. The field sampling was performed according to the ISO 5667-11 guidance (1993). The chemical analyses were performed at Adam Mickiewicz University in Poznan (Institute of Geology) using a Compact IC 881Pro ionic chromatograph. As a quality control measure, the ionic error balance was calculated. The calculated error did not exceed $3 \%$.

The analysis from the well constructed in 2008 in Wladyslawowo was included for this study. Water samples from the screen depth and from a depth of $30 \mathrm{~m}$ were collected from this well (Fig. 2a).

Archival physico-chemical analyses from the period of well construction were also used as well as data received from the local monitoring network of the landfill located in Bolewice. These samples were collected with a shallow piezometer (approximately $30 \mathrm{~m}$ in depth, Fig. 2b).

To identify the denitrification processes, measurements of the gaseous $\mathrm{N}_{2}$ dissolved in the groundwater were performed. The sample measurement, analysis and interpretation were completed according to the procedures presented by Zurek et al. (2010). Excess $\mathrm{N}_{2}$ (above equilibrium with atmospheric $\mathrm{N}_{2}$ ) was determined to be an indicator of denitrification. The samples used for dissolved gas analysis were collected in the field with the use of stainless vessels (doubled vessels for each water sample). The sealed connection between the vessels and the well creates an airproof condition to prevent degassing and contact between the water and the atmospheric air. Doubled samples were taken to indicate potential leaks (in case one sample leaked). The analyses were carried out in the laboratory of the Polish Academy of Science (Institute of 
Nuclear Physics) in Cracow using the gas chromatographic method.

The tritium content was measured in four water samples and expressed as tritium units (TU). Isotope analyses were performed in the laboratory of the AGH University of Science and Technology (Faculty of Physics and Applied Computer Science) in Cracow.

\section{Results}

\section{Groundwater chemistry}

For such a small study area, relatively distinctive groundwater chemistry variations were present (Fig. 4; Table 1). The smallest electrical conductivity (EC) and total hardness $(\mathrm{TH})$ are observed in the central part of the study area, in the region of unconfined condition occurrence (Jozefowo and Wladyslawowo regions-Fig. 2). A similar differentiation is characteristic of the alkalinity, but its concentration is smaller than that of the TH. The concentrations of all of the mentioned parameters increase along flow lines (compare Figs. 3, 4) and are the highest in Bolewice (southern direction) and Pniewy (northern direction). At a greater distance than Bolewice, smaller concentrations of

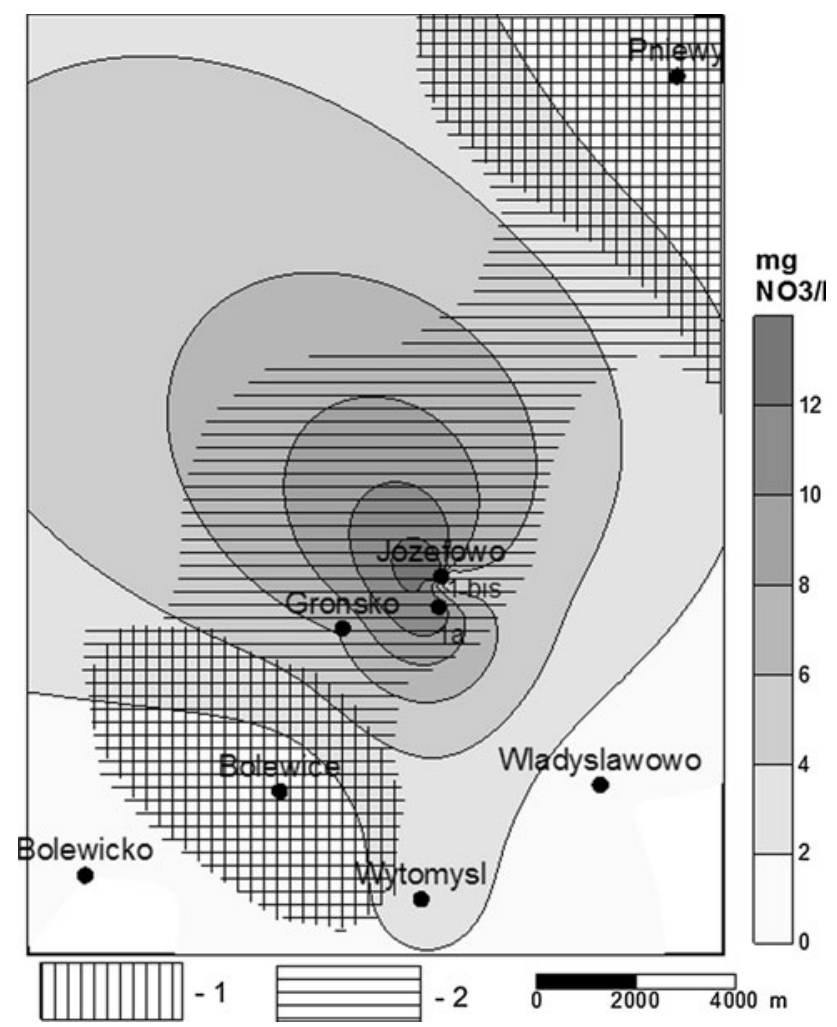

Fig. 4 Changes in the hydrochemical parameters against a background of the nitrate concentrations. 1 Total hardness $>6.0 \mathrm{mval} / \mathrm{l}, 2$ sulphate $>70 \mathrm{mg} / \mathrm{l}$ these parameters occur again (Bolewicko and Wytomysl regions). The sulphate concentrations are the highest in Jozefowo, Pniewy and Bolewice. The chloride concentration is relatively small throughout the study region, with the highest concentrations occurring in Bolewice and Pniewy. The groundwater in the well located in Chmielinko diverges completely; this sample was removed from the map. This groundwater is characterised by relatively high TH (despite its location in the central part of the region, near Jozefowo). The $\mathrm{TH}$ is balanced by the alkalinity. Moreover, very low concentrations of chloride, sulphate and nutrients are visible in this well.

The most distinct variation is found in nitrate and nitrite concentrations. Both parameters are the highest in the Jozefowo and Gronsko regions (the unconfined part of the aquifer). In the wells around this region, the concentrations of both nutrients are very small (Fig. 4). Importantly, nitrate appears in the central part of the recharge area, even in deep wells (Fig. 5).

In almost every well, distinct groundwater changes over time are evident. The most intensive changes occur in the sulphate concentration. An increase in the chloride concentration is also visible, but its range is clearly smaller (Fig. 6a). A significant increase in the $\mathrm{TH}$ is also clear (Fig. 6b). Furthermore, during the period of the wells' construction, the $\mathrm{TH}$ was balanced by alkalinity (reflecting the $\mathrm{HCO}_{3}$ concentration). On the graph, most of the points are located close to the $\mathrm{TH}=$ alkalinity (i.e. $\mathrm{Ca}+\mathrm{Mg}=\mathrm{HCO}_{3}$ ) line. However, current groundwater chemistry analyses exhibit a surplus of $\mathrm{TH}$ relative to the alkalinity (most of the points are located over the $\mathrm{Ca}+\mathrm{Mg}=\mathrm{HCO}_{3}$ line). This observation may suggest the occurrence of non-carbonate hardness balanced mainly by high sulphate concentrations.

The exception to this variation is the well located in Chmielinko, where no distinct groundwater chemistry changes were documented over time. The unique groundwater chemistry of this well confirms that the deepest aquifers are isolated hydraulically from the shallower aquifer system.

The changes in the groundwater chemistry in wells located very close to each other should be noted. Well nos. $1 \mathrm{a}$ and 2 in Jozefowo are located at a distance of $100 \mathrm{~m}$ apart and have similar depths (Fig. 2). It is clear that in well 1a, a high concentration of nitrate occurs $(12.0 \mathrm{mg}$ $\mathrm{NO}_{3} / 1$ ), whereas in well no. 2 , the concentration of nitrate is only $2.16 \mathrm{mg} \mathrm{NO} / \mathrm{l}$. A similar differentiation is found in the nitrite concentration (Table 1). However, a higher $\mathrm{TH}$, alkalinity and sulphate occur in well no. 2 (relative to well no. 1a).

The groundwater chemistry observed in the shallow part of the flow system (close to the water table) demonstrates the completely different nature of that water (Table 1). The 
Table 1 Groundwater chemistry in the deep part of the flow system

\begin{tabular}{|c|c|c|c|c|c|c|c|c|c|c|c|c|c|c|c|}
\hline No. & Location & $\begin{array}{l}\mathrm{pH} \\
(-)\end{array}$ & $\begin{array}{l}\mathrm{EC} \\
(\mu \mathrm{m} / \mathrm{cm})\end{array}$ & $\begin{array}{l}\mathrm{TH} \\
(\mathrm{mval} / \mathrm{l})\end{array}$ & $\begin{array}{l}\text { Alk } \\
\text { (mval/l) }\end{array}$ & $\begin{array}{l}\mathrm{Cl} \\
(\mathrm{mg} / \mathrm{l})\end{array}$ & $\begin{array}{l}\mathrm{SO}_{4} \\
(\mathrm{mg} / \mathrm{l})\end{array}$ & $\begin{array}{l}\mathrm{Na} \\
(\mathrm{mg} / \mathrm{l})\end{array}$ & $\begin{array}{l}\mathrm{K} \\
(\mathrm{mg} / \mathrm{l})\end{array}$ & $\begin{array}{l}\mathrm{NO}_{3} \\
(\mathrm{mg} / \mathrm{l})\end{array}$ & $\begin{array}{l}\mathrm{NO}_{2} \\
(\mathrm{mg} / \mathrm{l})\end{array}$ & $\begin{array}{l}\mathrm{NH}_{4} \\
(\mathrm{mg} / \mathrm{l})\end{array}$ & $\begin{array}{l}\mathrm{OC} \\
(\mathrm{mg} / \mathrm{l})\end{array}$ & $\begin{array}{l}\mathrm{Fe} \\
(\mathrm{mg} / \mathrm{l})\end{array}$ & $\begin{array}{l}\mathrm{Mn} \\
(\mathrm{mg} / \mathrm{l})\end{array}$ \\
\hline \multicolumn{16}{|c|}{ Deep part of the flow system } \\
\hline \multicolumn{16}{|c|}{ Wells located in the study area } \\
\hline 1 & Bolewice & 7.38 & 627 & 7.6 & 5.6 & 25.6 & 85.4 & 7.5 & 2.7 & $<0.01$ & $<0.01$ & 0.06 & 1.3 & 2.1 & 0.1 \\
\hline 2 & Bolewicko & 7.29 & 569 & 5.9 & 5.4 & 16.8 & 31.0 & 12.9 & 2.9 & $<0.01$ & $<0.01$ & 0.37 & 2.7 & 3.2 & 0.2 \\
\hline 3 & Chmielinko & 7.27 & 642 & & 6.4 & 3.86 & 8.4 & 10.9 & 3.4 & $<0.01$ & $<0.01$ & 0.54 & 1.8 & 2.9 & 0.18 \\
\hline 4 & Gronsko & 7.60 & 422 & 4.9 & 3.2 & 18.6 & 71.9 & 7.3 & 2.0 & 6.23 & 0.28 & 0.02 & 0.8 & 0.6 & 0.1 \\
\hline 5 & Jozefowo 1 bis & 7.41 & 592 & 5.7 & 3.6 & 25.0 & 79.2 & 6.6 & 2.6 & 13.76 & 0.26 & $<0.01$ & 0.5 & 0.1 & 0.1 \\
\hline 6 & Jozefowo 1a & 7.68 & 452 & 4.8 & 2.9 & 23.0 & 74.2 & 6.4 & 2.2 & 12.00 & 0.33 & $<0.01$ & 0.6 & 0.3 & 0.1 \\
\hline 7 & Jozefowo 2 & 7.15 & 587 & 6.7 & 4.3 & 28.1 & 92.3 & 7.4 & 2.6 & 2.16 & $<0.01$ & 0.09 & 0.8 & 0.9 & 0.2 \\
\hline 8 & Pniewy & 7.38 & 580 & 6.2 & 4.0 & 30.7 & 86.2 & 7.4 & 2.5 & $<0.01$ & $<0.01$ & 0.18 & 1.8 & 1.9 & 0.1 \\
\hline 9 & Wytomysl & 7.44 & 580 & 5.6 & 4.9 & 21.8 & 25.6 & 13.0 & 2.2 & 2.85 & $<0.01$ & 0.02 & 1.3 & 0.5 & 0.3 \\
\hline 10 & Wladyslawowo & 7.10 & 496 & 4.8 & 4.8 & 4.7 & 10.9 & 8.2 & 1.8 & 0.08 & 0.05 & 0.12 & 1.2 & 1.7 & 0.2 \\
\hline \multicolumn{16}{|c|}{ Wells located outside the study area } \\
\hline 11 & Kopanki & 7.84 & 314 & & 2.7 & 11.0 & 23.0 & 5.8 & 1.5 & $<0.01$ & $<0.01$ & 0.03 & 0.8 & 0.85 & 0.09 \\
\hline 12 & Satopy & 7.56 & 415 & & 3.6 & 16.0 & 32.0 & 7.7 & 2.4 & $<0.01$ & $<0.01$ & 0.20 & 1.8 & 2.2 & 0.26 \\
\hline \multicolumn{16}{|c|}{ Shallow part of the flow system } \\
\hline 1 & Bolewice P3 & 6.9 & 1,520 & 15.0 & 9.89 & 48.0 & 48.0 & 61.0 & 3.3 & 120.0 & 0.02 & 0.28 & - & 0.02 & 0.002 \\
\hline 2 & Wladyslawowo & 7.1 & 652 & 5.3 & 3.8 & 52.7 & 51.6 & 29.8 & 6.2 & 73.0 & 0.07 & 0.12 & 1.4 & 0.12 & 0.146 \\
\hline
\end{tabular}

EC electrical conductivity, $\mathrm{TH}$ total hardness, Alk alkalinity, $\mathrm{OC}$ oxygen consumption $\left(\mathrm{mgO}_{2} / \mathrm{l}\right)$
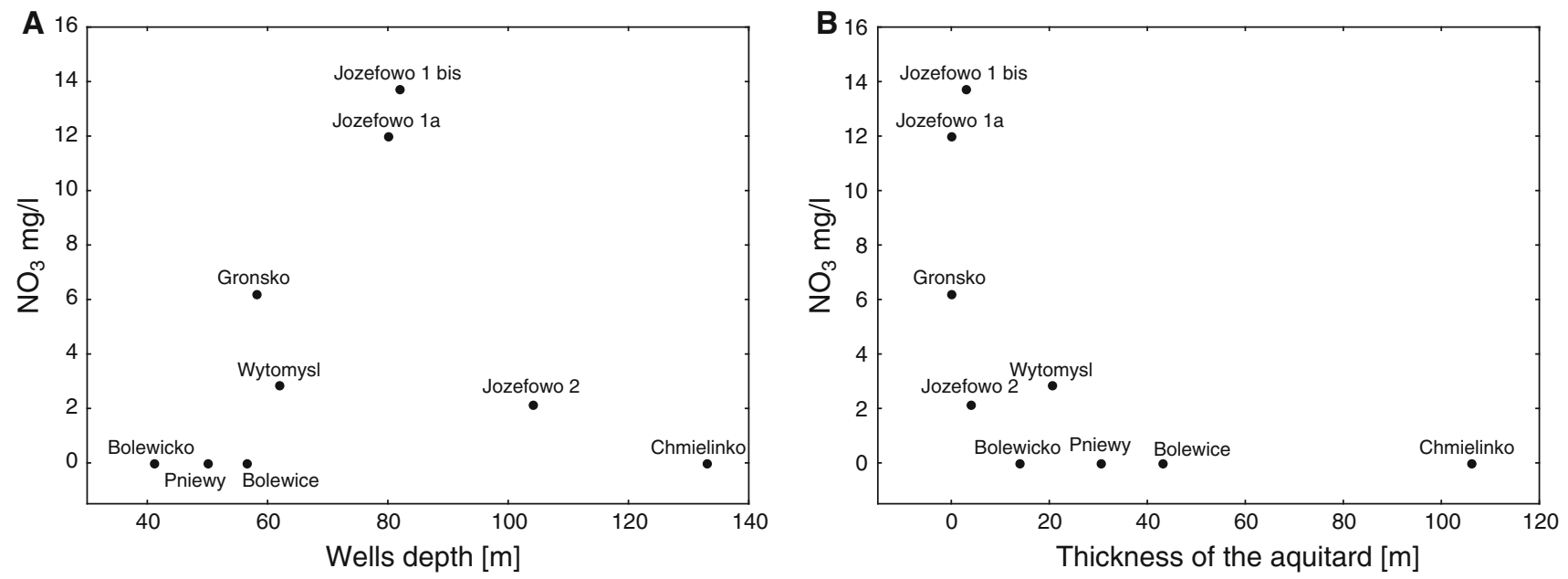

Fig. 5 Variation of the nitrate concentration with well depth and thickness of the aquitard

most distinctive factor is that a very high content of nitrate is visible (73-120 $\left.\mathrm{mg} \mathrm{NO}_{3} / \mathrm{l}\right)$. Moreover, the water in the shallow part of the flow system is characterised by a higher concentration of chloride and a lower concentration of sulphate.

\section{Excess dissolved $\mathrm{N}_{2}$}

The groundwater in the study area contains a relatively high concentration of excess $\mathrm{N}_{2}$ (Table 2). The range of $\mathrm{N}_{2}$ excess varies from 6.22 to $8.62 \mathrm{mg} \mathrm{N} / 2$. The highest concentration was detected in well no. 2 in Jozefowo. In Jozefowo well no. 1b (which is located very close to
Jozefowo well no. 2), the concentration of excess $\mathrm{N}_{2}$ was found to be lower $\left(6.56 \mathrm{mg} \mathrm{N}_{2} / \mathrm{l}\right)$.

Two samples were collected outside the study area for the measurement of excess $\mathrm{N}_{2}$ in the recharge zone of the Wielkopolska Buried Valley Aquifer. The sampled wells are located several kilometres south of the study area (Fig. 1). This is also a zone where favourable aquifer recharge occurs, which has been documented based on chemical data (Dragon and Górski 2009). The hydrogeological conditions of these sites are similar to those presented in Fig. 2a in the well Kozielaski vicinity. The differences in the attributes of these sites (relative to the study area) are due to their different types of land use. 

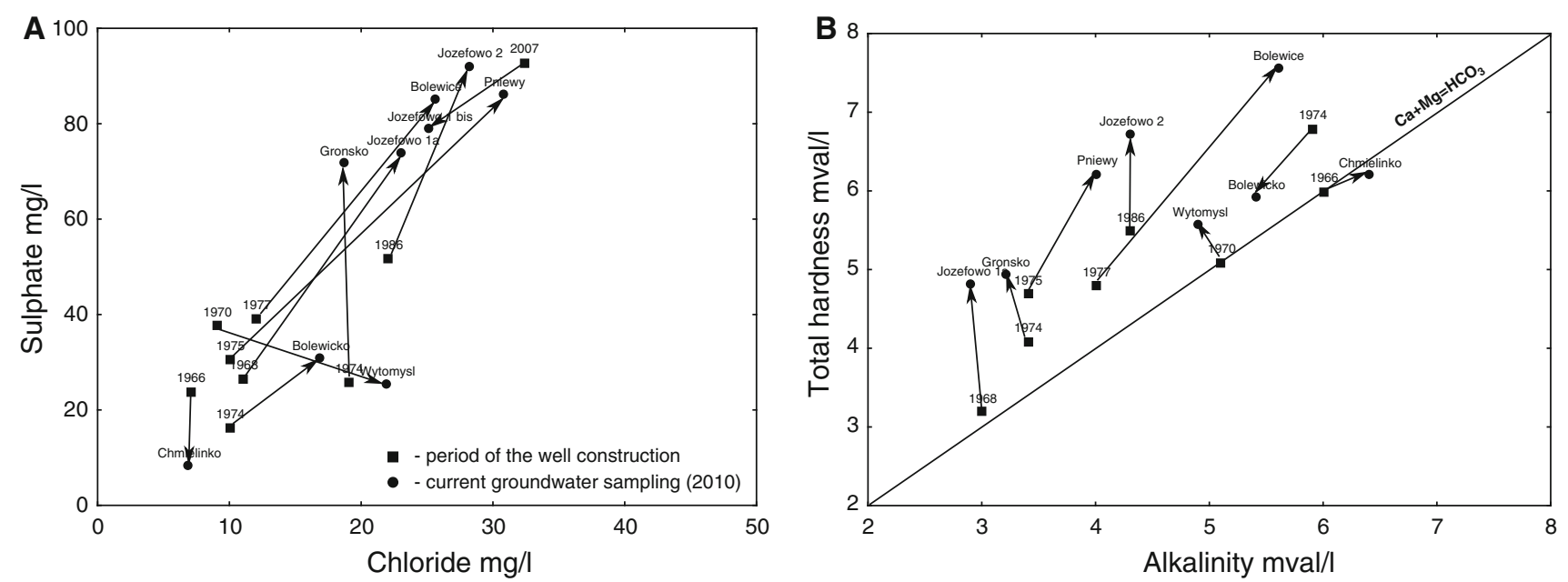

Fig. 6 Changes of groundwater chemistry during wells' exploitation

Table 2 Result of the tritium analyses and $\mathrm{N}_{2}$ excess measurements

\begin{tabular}{lllll}
\hline No. & Location & Tritium $(\mathrm{T} . \mathrm{U})$ & Measured $\mathrm{N}_{2}\left(\mathrm{mg} / \mathrm{l} \times 10^{-1}\right)$ & Excess $\mathrm{N}_{2}(\mathrm{mg} / \mathrm{l})$ \\
\hline 1 & Bolewice & $5.1 \pm 0.4$ & $2.68 \pm 0.06$ & $6.22 \pm 0.7$ \\
4 & Grońsko & $4.4 \pm 0.4$ & $2.63 \pm 0.06$ & $6.45 \pm 0.8$ \\
5 & Józefowo 1 bis & $3.6 \pm 0.3$ & $2.69 \pm 0.06$ & $6.56 \pm 0.6$ \\
7 & Józefowo 2 & - & $2.92 \pm 0.06$ & $8.62 \pm 0.5$ \\
8 & Pniewy & $4.0 \pm 0.4$ & $2.58 \pm 0.09$ & $6.88 \pm 0.8$ \\
11 & Kopanki & - & $2.47 \pm 0.06$ & $3.82 \pm 0.8$ \\
12 & Satopy & - & $2.87 \pm 0.08$ & $4.88 \pm 1.3$ \\
\hline
\end{tabular}

The Kopanki and Satopy wells (Table 2) are located in a region where forest dominates and there is little arable land. Therefore, it is notable that the excess $\mathrm{N}_{2}$ concentration is much lower in these wells, ranging between 3.82 and $4.88 \mathrm{mg} \mathrm{N}_{2} / \mathrm{l}$.

\section{Discussion}

Groundwater that occurs at a shallow depth (just below the water table) is strongly influenced by human activities (Table 1). This is clearly visible in the Wladyslawowo well. A very high concentration of nitrate $\left(72.0 \mathrm{mgNO}_{3} / \mathrm{l}\right)$ and high concentrations of chloride (52.7) and sulphate $(51.6 \mathrm{mg} / \mathrm{l})$ show that both sources of pollution-agricultural activity as well as developed areas without sewerage systems-influence groundwater chemistry. This effect is also visible in the piezometer located in Bolewice; however, this water is also influenced by the landfill in the area. In the regions where the unconfined conditions occur, these contaminants can migrate to deeper parts of the flow system. The influence of the contaminants is visible mainly in regions where long-term groundwater extraction is performed. In Jozefowo, the influence of contaminants (particularly, the high nitrate concentration) is visible in all of the wells. In a well located in a region of unconfined conditions where groundwater extraction does not occur (the Wladyslawowo well), the influence of contaminants is not yet visible. The comparison of nitrate concentrations in the Jozefowo and Wladyslawowo wells may suggest that the process of the contaminants' downward migration is activated by the natural downward gradient but is intensified considerably by groundwater extraction. The cone of depression causes a higher downward gradient than occurs naturally. In the well located in Wladyslawowo, if groundwater extraction is performed, it is expected that a deterioration of water chemistry will appear (mainly in an increased nitrate concentration).

Important groundwater chemistry changes are visible in the part of the recharge area where confined conditions occur. Groundwater chemistry changes during well exploitation are visible in almost all the wells. The most intensive increases appear in the sulphate concentration and total hardness. The least important changes occur in the case of chloride (Fig. 6). Furthermore, there is a lack of nitrate in almost all wells (Table 1). This finding is incongruent with previous work performed in the Wielkopolska region (Górski 1989; Dragon 2008), which found that the main product of urbanisation was chloride (sulphate was also found but was less considerable). This result 
may suggest the involvement of mechanisms of groundwater chemistry change due to contamination that differ from the mechanisms involved in the regions surrounding the study area.

The high sulphate concentration and total hardness, in conjunction with the small nitrate concentration (or even the lack of nitrate in the water), can be interpreted as a result of denitrification. The increase in the chloride concentration (which is less considerable than the sulphate level) indicates that the contamination (the product of denitrification that is present in the shallow part of the flow system) is derived mainly from areas without sewerage system. It has been documented that domestic sewage contamination adds to groundwater chloride, sulphate and nitrate (Hudak and Blanchard 1997). In the study area, the influence of settlement and the application of manure to the land surface appear to be the most important sources of contamination. It is important to recognise that the influence of this source of contamination dates back to previous centuries (Dragon 2008).
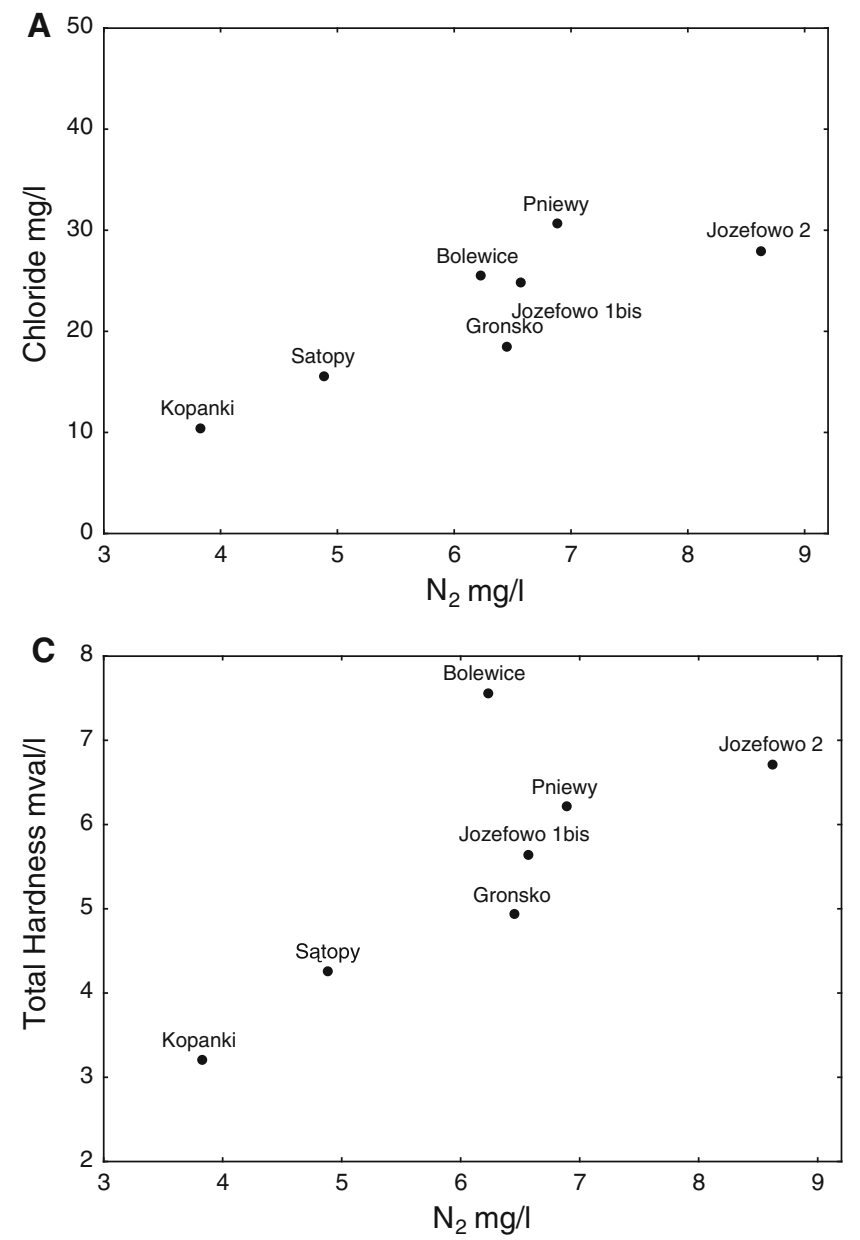

The occurrence of denitrification is also confirmed by the excess $\mathrm{N}_{2}$ measurement. The concentration of gaseous excess $\mathrm{N}_{2}$ documented within the study area is characteristic of the denitrification influence (Table 2, Fig. 7). A similar excess of $\mathrm{N}_{2}$ originating in denitrification has been previously documented elsewhere (Bennekom et al. 1993; Blicher-Mathiesen et al. 1998; Craig et al. 2010; Welch et al. 2011). Importantly, the excess of $\mathrm{N}_{2}$ is much lower in wells located in recharge areas covered by forested land (the Kopanki and Sapowice wells, Fig. 7). The denitrification was documented in the entire study area across both the confined and unconfined parts of the flow system. It is believed that the confined part of the flow system is more favourable for denitrification than the unconfined parts (Rivett et al. 2008). The existence of highly contaminated groundwater with a high nitrate content in the shallow part of the flow system and the absence of nitrate (and the presence of denitrification products: sulphate, total hardness and excess $\mathrm{N}_{2}$ ) in deeper aquifers (Fig. 7) in conjunction with a high downward gradient (Fig. 2) indicate
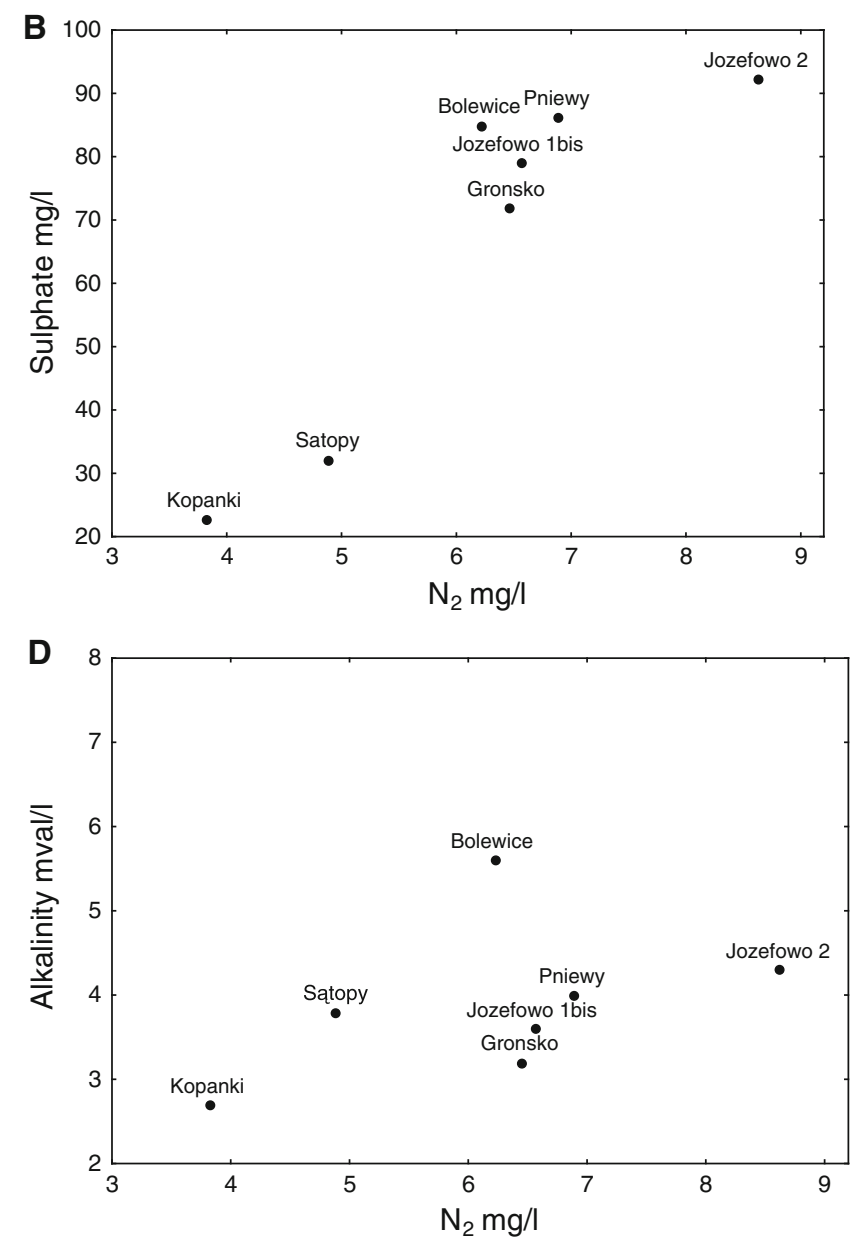

Fig. 7 The scatter diagrams of gaseous $\mathrm{N}_{2}$ and some hydrochemical parameters 
that the process of denitrification exists within the aquitard. It is possible that the aquitard sediments contain an electron donor, such as organic carbon or sulphur compounds (Robertson et al. 1995; Rodvang and Simpkins 2001). The nature of the groundwater chemistry changes (low alkalinity, high sulphate and total hardness) suggests that autotrophic denitrification prevails in the studied system (Rivett et al. 2008).

The high concentration of excess $\mathrm{N}_{2}$ indicates that denitrification is also present in the unconfined parts of the flow system (Fig. 7). The presence of nitrate in this part of the flow system at great depth (Fig. 5) is possible if there is a preferential flow caused by a high downward gradient. This preferential aquifer recharge causes the migration of highly contaminated groundwater (with a high nitrate content) from the near-surface zone to the deepest part of the flow system. The high nitrate concentration appears in the wells located in the areas that are the most vulnerable to pollution, such as Jozefowo 1a and Jozefowo 2. In the profile of Jozefowo well no. 1a, yellow, coarse sands and gravels occur in the aeration zone as well as in the deepest part of the saturation zone. This environment facilitates relatively rapid contaminant migration; at the same time, this type of sediment is not favourable for denitrification. In contrast, in the profile of Jozefowo well no. 2, grey, fine and silty sands occur. This sediment is more favourable for denitrification, but a lower velocity of contaminant migration occurs there. As a result, distinct changes in the water chemistry are visible between these wells, even though the wells are located very close to each other (the distance between them is approximately $100 \mathrm{~m}$ ) and have similar depths. In well no. 1a, a high concentration of nitrate occurs (considerable higher than in well no. 2), whereas in well no. 2, the highest concentrations of denitrification indicators (mainly sulphate, total hardness and excess $\mathrm{N}_{2}$ ) appear (Fig. 7). In contrast, the Bolewicko well is also located in a part of the aquifer that is vulnerable to contamination due to its small aquitard thickness (Fig. 2b), but the recharge area of this well is located in forested land. As a consequence, there are no indicators of pollution in this well (very low chloride concentration). The total hardness and sulphate concentrations (denitrification products) are also very low, suggesting that denitrification does not occur there due to the lack of pollution sources in the region.

These conclusions are supported by the tritium analysis. A relatively high content of tritium was detected in all of the measured samples, indicating a post-1951 recharge to the aquifer (Table 2). The absence of nitrate, the presence of denitrification products (sulphate, total hardness and excess $\mathrm{N}_{2}$ ) and the simultaneous relatively high tritium content in all the measured samples (in both the confined and unconfined parts of the flow system) strongly confirm the presented conclusions. High tritium content confirms possibility of easy contaminant migration, but absence of nitrate in the deep part of the flow system (while nitrate is present in shallow flow system) confirms the occurrence of denitrification.

The conceptual model of groundwater circulation is presented in Fig. 8. The most intensive aquifer recharge occurs in the unconfined parts of the flow system. In these regions, the groundwater occurring in the shallow part of the aquifer is highly contaminated (mainly by nitrate). In the region of groundwater extraction, these contaminants migrate downward to the deep part of the flow system. Under natural conditions, this contamination is not yet observed in the deep part of the flow system, which may be due to the presence of a stagnation zone in the flow field (the zone located between fields of opposite flow directions) (Fetter 1994). In this zone, the flow path diverges to the

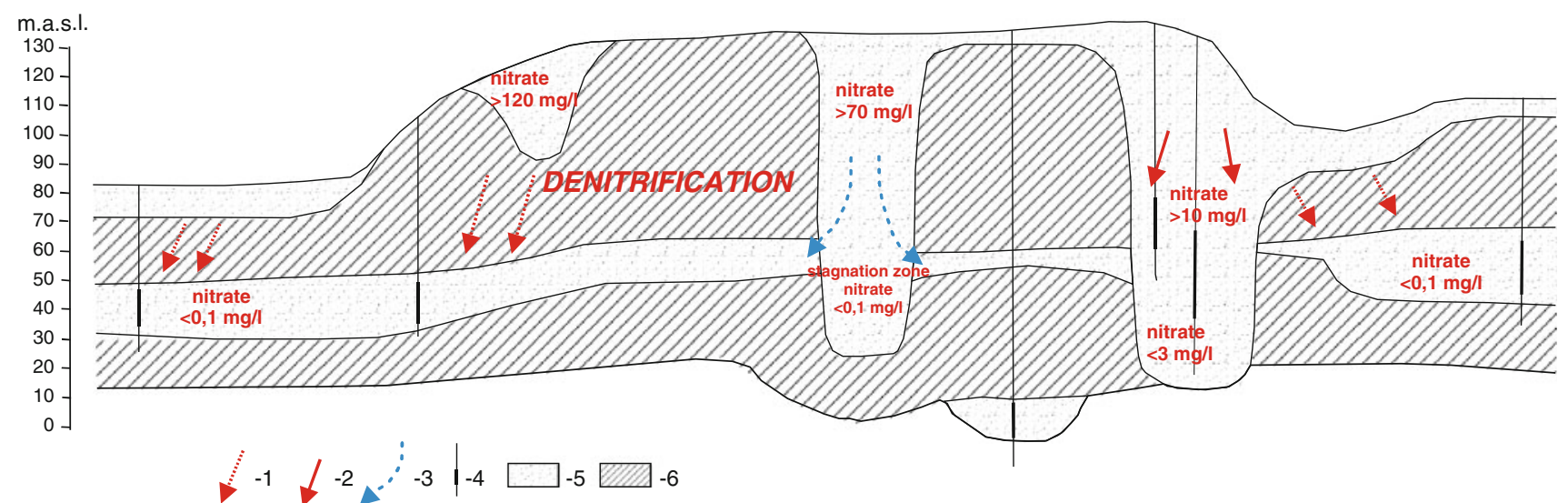

Fig. 8 A conceptual model of the groundwater circulation and behaviour of the nitrate in the regional recharge zone of the Quaternary flow system. 1 The preferential aquifer recharge through the aquitard, 2 the preferential aquifer recharge-the unconfined parts of the flow system and the regions of intensive groundwater exploitation, 3 the aquifer recharge under natural groundwater flow conditions (without exploitation), 4 wells in regions of intensive groundwater exploitation, 5 aquifers, 6 aquitard 
south and north and surrounds the stagnation zone (Fig. 8). In the areas where the aquitard covers the aquifers, a high nitrate concentration is not present in the confined aquifers, even if there is a high nitrate concentration in the shallow zone. However, as a consequence of the denitrification processes, a high concentration of sulphate and $\mathrm{TH}$ appear in the deep aquifers. Furthermore, these waters contain high concentrations of gaseous $\mathrm{N}_{2}$. The high tritium concentration confirms that these waters originate from a downward migration through the aquitard. This downward migration is the most intensive in regions of groundwater exploitation. The observation of groundwater chemistry changes along flow lines indicates that spatial groundwater chemistry is primarily dependent on a vertical preferential water recharge (caused by a downward gradient).

The presence of a very high nitrate concentration in the shallow part of the flow system and a downward gradient that displaces the contamination front to the deeper parts of the aquifer generate a "time bomb" with an "explosion" that is accelerated by water extraction. The mixing of contaminated groundwater with unpolluted groundwater from deeper parts of the flow system is the factor that reduces the risk of deep-water contamination.

\section{Conclusion}

The groundwater chemistry occurring in the recharge zone of the Quaternary flow system (Wielkopolska region, Poland) is highly dependent on the conditions of the groundwater flow. In the near-surface zone of the aquifers (at a depth of approximately $30 \mathrm{~m}$, close to the groundwater level), a distinct groundwater contamination was detected, indicated mainly by its high nitrate concentrations. Tritium concentrations observed in the deep parts of the flow system confirm that contaminants from shallow zone can migrate easily to the deepest parts of the aquifer, even under confined conditions. The factor that enables this downward migration is the distinct downward gradient that is characteristic of the regional recharge zones. This downward gradient is further accentuated in regions of groundwater extraction by creating a cone of depression, facilitating the migration of contaminants. A high concentration of nitrate was discovered at great depth in the unconfined part of the flow system, which is the area most vulnerable to pollution. In the deeper part of the flow system, an absence of nitrate was observed in the region of confined conditions, but higher concentrations of sulphate and total hardness appear during well exploitation. There is also an increase in the chloride concentration, but it is less important than the other increases. It is important to note that although the high nitrate concentration occurs in the shallow zone in the regions under confined conditions, nitrate does not occur in deep aquifers. Denitrification is the process of nitrate removal from groundwater. As a result, an increase in the sulphate and total hardness appears in the groundwater. The nature of the groundwater chemistry changes (low alkalinity, high sulphate and total hardness) suggests that autotrophic denitrification which uses sulphate compounds as electron donors prevails in the studied system. The process of denitrification was confirmed by the existence of a high gaseous $\mathrm{N}_{2}$ concentration. Denitrification occurs in both the confined and unconfined parts of the flow system. The potential for denitrification is higher in the confined condition and leads to an overall decline in nitrate in the deep aquifers. In the unconfined part of the flow system, which is the most vulnerable to pollution from the surface, a high concentration of nitrate was discovered at a great depth. This is caused by both its more intensive aquifer recharge, which causes a more intensive groundwater contamination, and its low denitrification potential, which is insufficient to completely remove nitrate from the groundwater.

The study shows that the recharge area of the regional flow system is extremely vulnerable to pollution by nitrate. It is connected mainly to unconfined aquifers where high thickness of the aeration zone occurs that are exposed to numerous sources of pollution. The high vulnerability is a reason of favourable conditions for nitrification of nitrogen contaminants in the aeration zone. Similar conditions can be expected in the regions of terminal moraines elevations and edge zones of deep valleys and ice-marginal valleys. The monitoring of groundwater chemistry at these regions should be performed for both shallow and deep parts of the flow system, though the shallow part is not used for water supply purposes. It is expected that in the long-term perspective, the quality of the deep groundwater will be deteriorated if shallow contaminated groundwater penetrates the aquifer.

Acknowledgments The author would like to thank Prof. Dr. Jozef Górski for his valuable contributions to this subject and important discussions during the study period. This work was made possible by the financial support of the Ministry of Science and Higher Education (grant no. 2164/BT02/2007/33).

Open Access This article is distributed under the terms of the Creative Commons Attribution License which permits any use, distribution, and reproduction in any medium, provided the original author(s) and the source are credited.

\section{References}

Aravena R, Robertson WD (1998) Use of multiple isotope tracers to evaluate denitrification on ground water: study of nitrate from large-flux septic system plume. Ground Water 36(6):975-982

Bennekom CA, Kruithof JC, Krajenbrink GJW, Kool HJ (1993) Effect of nutrient leaching on groundwater and drinking water. Water SRT Aqua 42(2):77-87 
Blicher-Mathiesen GB, McCarty GW, Nielsen LP (1998) Denitrification and degassing in groundwater estimated from dissolved dinitrogen and argon. J Hydrol 208:16-24

Chen J, Tang C, Sakura Y, Yu J, Fukushima Y (2005) Nitrate pollution from agriculture in different hydrogeological zones of the regional groundwater flow system in the North China Plain. Hydrogeol J 13:481-492

Council Directive 91/676/EEC of 12 December 1991 concerning the protection of waters against pollution caused by nitrates from agricultural sources

Council Directive 98/83/EC of 3 November 1998 on the quality of water intended for human consumption

Craig L, Bahr JM, Roden EE (2010) Localized zones of denitrification in a floodplain aquifer in southern Wisconsin, USA. Hydrogeol J 18(8):1867-1879

Dabrowski S (1999) Dokumentacja hydrogeologiczna regionu Poznańskiego Dorzecza Warty zawierająca ocenę zasobów dyspozycyjnych wód podziemnych z utworów czwartorzędowych i trzeciorzędowych (The hydrogeological documentation of the Poznan part of the Warta Valley region with estimation of the regional groundwater resources from Quaternary and Tertiary reservoirs). Ministry of the Environment, Warsaw

Dragon K (2008) The influence of anthropogenic contamination on the groundwater chemistry of a semi-confined aquifer (the Wielkopolska Buried Valley Aquifer, Poland). Water Resour Manag 22(3):343-355

Dragon K, Górski J (2009) Identification of hydrogeochemical zones in postglacial buried valley aquifer (Wielkopolska Buried Valley aquifer, Poland). Environ Geol 58(4):859-866

Einsield F, Maloszewski P, Stichler W (2005) Estimation of denitrification potential in a karst aquifer using ${ }^{15} \mathrm{~N}$ and ${ }^{18} \mathrm{O}$ isotopes of $\mathrm{NO}_{3}$. Biogeochemistry 72:67-86

Feast NA, Hiscock KM, Dennis PF, Andrews JN (1998) Nitrogen isotope hydrochemistry and denitrification within the Chalk aquifer system of north Norfolk, UK. J Hydrol 211:233-252

Fetter CW (1994) Applied hydorogeology, 3rd edn. Macmillan College Publishing Company, New York

Górski J (1989) Główne problemy chemizmu wód podziemnych utworów kenozoiku środkowej Wielkopolski (The main hydrochemical problems of cainozoic aquifers located in Central Wielkopolska (Great Poland). Zeszyty Nauk. AGH:45 Kraków
Hudak PF (2000) Regional trends in nitrate content of Texas groundwater. J Hydrol 228:37-47

Hudak PF, Blanchard S (1997) Land use and groundwater quality in the Trinity group outcrop of north-central Texas, USA. Environ Int 23(4):507-517

ISO 5667-11 (1993) Water quality_sampling_part 11: guidance on sampling of groundwaters. International Organization for Standardization, Geneva

Kleczkowski AS (ed) (1990) Mapa obszarów Głównych Zbiorników Wód Podziemnych (GZWP) w Polsce wymagających szczególnej ochrony. The map of the critical protection areas of the major groundwater basins (MGWB) in Poland. Institute of Hydrogeology and Engineering Geology, Academy of Mining and Metallurgy, Cracow

Rozporządzenie Ministra Zdrowia z dnia 29 marca 2007 r. w sprawie jakości wody przeznaczonej do spożycia przez ludzi (Dz. U. z dnia 6 kwietnia 2007 r.)

Rivers CN, Barrett MH, Hiscock KM, Dennis PF, Feast NA, Lerner DN (1996) Use of nitrogen isotopes to identify nitrogen contamination of the Sherwood sandstone aquifer beneath the city of Nottingham, United Kingdom. Hydrogeol J 4(1):90-102

Rivett MO, Buss SR, Morgan P, Smith JWN, Bemment CD (2008) Nitrate attenuation in groundwater: a review of biogeochemical controlling processes. Water Res 42:4215-4232

Robertson WD, Russell BM, Cherry JA (1995) Attenuation of nitrate in aquitard sediments of southern Ontario. J Hydrol 180:267-281

Rodvang SJ, Simpkins WW (2001) Agricultural contaminants in Quaternary aquitards: a review of occurrence and fate in North America. Hydrogeol J 9:44-59

Welch HL, Greek CT, Coupe RH (2011) The fate and transport of nitrate in shallow groundwater in Northwestern Missisipi, USA. Hydrogeol J 19:1239-1252

World Health Organization (2004) Guidelines for drinking water quality, 3rd edn. WHO, Geneva

Zurek A, Rozanski K, Mochalski P, Kuc T (2010) Assessment of denitrification rate in fissured-karstic aquifer near Opole (SouthWest Poland): combined use of gaseous and isotope tracers. Biuletyn PIG 441:209-216 